\title{
Documentation of a Linked-Population Viability Model (LPVA) to Evaluate Recovery Options for Snake River Fall Chinook Salmon
}

November, 2013

Prepared by

H. I. Jager

With contributions from

J. A. Chandler

P. Groves

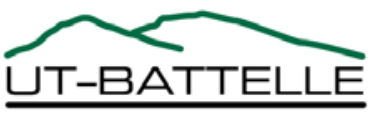




\section{DOCUMENT AVAILABILITY}

Reports produced after January 1, 1996, are generally available free via the U.S.

Department of Energy (DOE) Information Bridge.

Web site http://www.osti.gov/bridge

Reports produced before January 1, 1996, may be purchased by members of the public from the following source.

National Technical Information Service

5285 Port Royal Road

Springfield, VA 22161

Telephone 703-605-6000 (1-800-553-6847)

TDD 703-487-4639

Fax 703-605-6900

E-mail info@ntis.fedworld.gov

Web site http://www.ntis.gov/support/ordernowabout.htm

Reports are available to DOE employees, DOE contractors, Energy Technology Data Exchange (ETDE) representatives, and International Nuclear Information System (INIS) representatives from the following source.

Office of Scientific and Technical Information

P.O. Box 62

Oak Ridge, TN 37831

Telephone 865-576-8401

Fax 865-576-5728

E-mail reports@adonis.osti.gov

Web site http://www.osti.gov/contact.html

This report was prepared as an account of work sponsored by an agency of the United States Government. Neither the United States Government nor any agency thereof, nor any of their employees, makes any warranty, express or implied, or assumes any legal liability or responsibility for the accuracy, completeness, or usefulness of any information, apparatus, product, or process disclosed, or represents that its use would not infringe privately owned rights. Reference herein to any specific commercial product, process, or service by trade name, trademark, manufacturer, or otherwise, does not necessarily constitute or imply its endorsement, recommendation, or favoring by the United States Government or any agency thereof. The views and opinions of authors expressed herein do not necessarily state or reflect those of the United States Government or any agency thereof. 


\title{
DOCUMENTATION OF A LINKED-POPULATION VIABILITY MODEL (LPVA) TO EVALUATE RECOVERY OPTIONS FOR SNAKE RIVER FALL CHINOOK SALMON
}

H. I. Jager

\author{
J.A. Chandler \\ P. Groves
}

November 2013

\author{
Prepared for: \\ IDAHO POWER COMPANY \\ by \\ OAK RIDGE NATIONAL LABORATORY \\ Oak Ridge, Tennessee 37831-6283 \\ managed by \\ UT-BATTELLE, LLC \\ for the \\ U.S. DEPARTMENT OF ENERGY \\ under contract DE-AC05-00OR22725
}




\section{TABLE OF CONTENTS}

Page

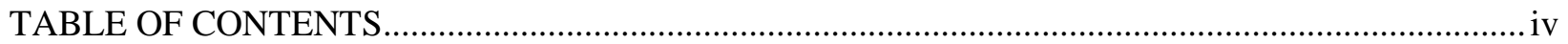

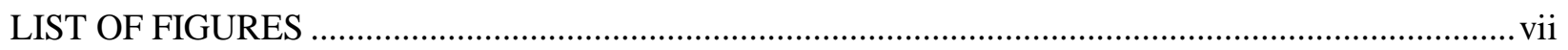

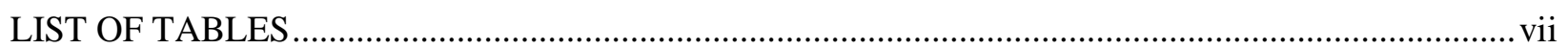

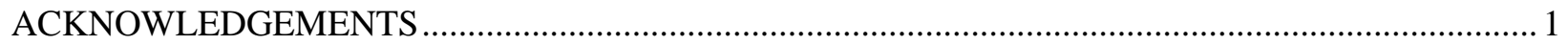

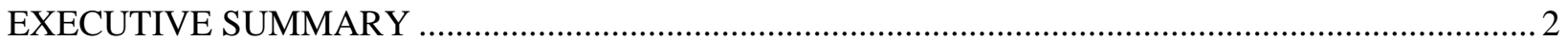

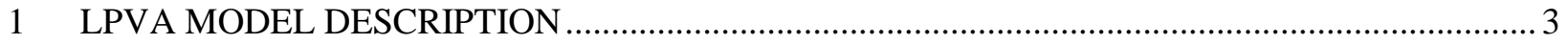

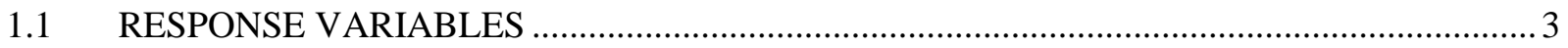

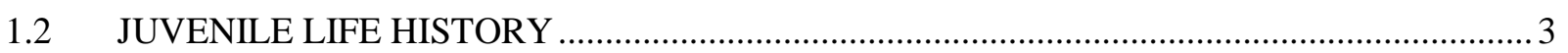

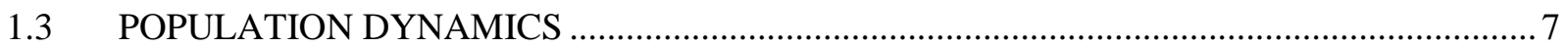

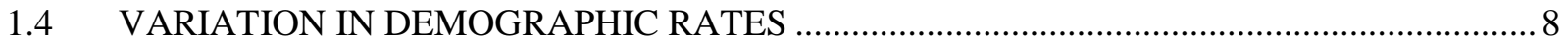

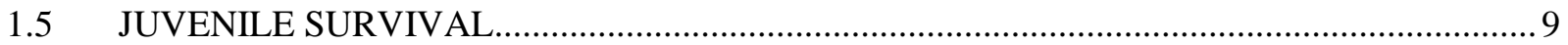

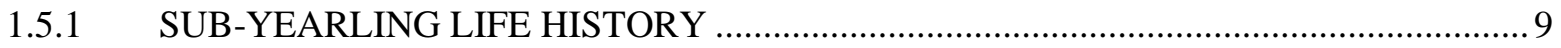

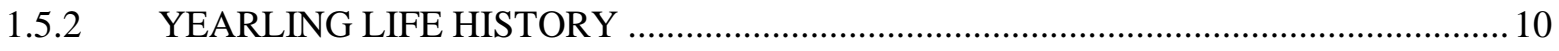

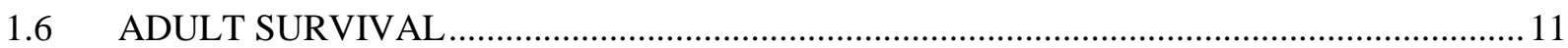

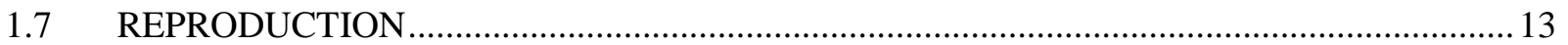

2 BAYESIAN MULTI-PARAMETER MODELING \& SENSITIVITY ANALYSIS ......................... 14

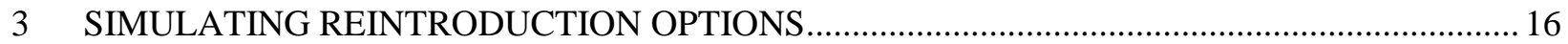

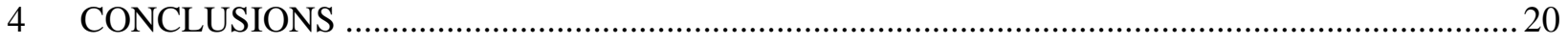

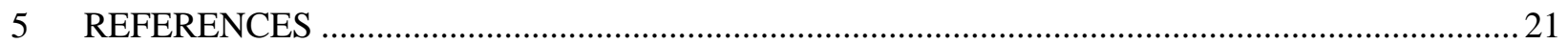




\section{LIST OF FIGURES}

\section{Figures}

Figure 1. Size-dependent model of ocean survival between limits $S_{o c, \min }$ and $S_{o c, \max } \ldots \ldots \ldots \ldots \ldots \ldots \ldots \ldots \ldots \ldots . . . . . . . . . . . .12$ Figure 2. Ocean and in-river exploitation rates (percent of upmigrating spawners counted at Bonneville Dam) for Snake River fall Chinook. Source: (NOAA Fisheries 2008). 12 Figure 3. MCMC-estimated posterior distributions of four poorly-known parameters, a) $K_{\text {trap_min }}$, b) $S_{E G G \text {, }}$

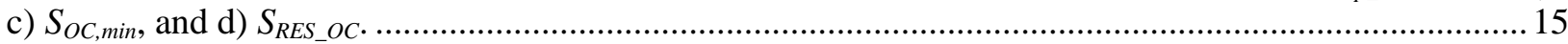

Figure 4. Diagram of the simulated reintroduction decision process..................................................... 17

\section{LIST OF TABLES}

\section{Tables}

Table 1. Parameters in the Snake River fall Chinook metapopulation model. Acronyms include Hells Canyon (HC) population and dam, Lower Granite (LG), ....................................................................... 2

Table 2. Summary of stochastic models for demographic rates in the LPVA.......................................... 4 Table 3. Input parameters by age include the initial allocation of individuals by age, and the cumulative proportion of female spawners returning to the mainstem Snake River. Stable age distribution was used to estimate Pinit_age. The likelihood of spawning at age $\mathrm{x}+1$, given survival to age $\mathrm{x}$ is obtained from Cmature (mean) and Cmat_CV (CV). Values are based on adult returns to Lyon's Hatchery between 1990 and 2006 (excluding 1995-7, 2001) (Milks et al. 2009).

Table 4. Parameters of prior distributions and hyper-parameters used in estimating the posterior distribution of four poorly known LPVA parameter consistent with available historical data for spawner returns.

Table 5. Marks distinguishing Snake River fall Chinook salmon caught and released at different locations. 


\section{ACKNOWLEDGEMENTS}

This research was supported by Idaho Power Company, Boise, Idaho under Work-for-Others contract with ORNL NFE-06-00450. The assistance of Leslie Lauder in formatting this report is appreciated, as is a thorough collegial review by Mike Kelly. 


\section{EXECUTIVE SUMMARY}

We developed an age- and life-history based population viability analysis model for linked populations of fall Chinook salmon (LPVA). LPVA was designed to quantify the costs and benefits of re-establishing access to an upstream spawning area using managed reconnection options such as hatchery stocking and translocation. The model incorporates stochasticity in the age at which salmon return to spawn, sex ratio, juvenile life history, and survival rates. Response variables include the proportion of replicate populations that persisted for $80 \mathrm{y}$ (roughly 20 generations), the linked population's growth rate, $\lambda$, time to extinction and summaries of population sizes including average female spawner abundance, final female spawner abundance, and total female abundance. This report attempts to provide a complete model description, including simulation of management options and options for simulating forward with a joint distribution of parameters based on their likelihoods with respect to historical data. Intermediate results illustrating the Bayesian approach to identifying poorly-known parameters are reported here. LPVA simulates reconnection of linked populations by representing management processes such as trapping of adults migrating upstream at two dams and juveniles migrating downstream, and hatchery operations for one or two hatcheries. The purpose of the model is to support efforts to recover the threatened Snake River fall Chinook salmon ESU by evaluating population viability using existing spawning areas with and without a hatchery and to assess the potential costs and benefits of programs to re-establish an upstream spawning area.

For further information or submission of comments, please contact:

Principal Investigator: Henriette (Yetta) Jager

Oak Ridge National Laboratory

P.O. Box 2008, MS 6036

Oak Ridge, TN 37831

Phone: (865) 574-8143

E-mail: jagerhi@.ornl.gov 


\section{LPVA MODEL DESCRIPTION}

We developed an age- and life-history based PVA model for linked populations (LPVA) designed to quantify the costs and benefits of re-establishing access to an upstream spawning area using managed reconnection options such as hatchery stocking and translocation. The model incorporated stochasticity in age-at-return, sex ratio, juvenile life history, and survival rates. The population viability model described here consists of groups defined by four attributes: 1) spawning area (population), 2) age in years, 3) juvenile life history, and 4) markings indicating trapping or release history. Scalar parameters for the LPVA model are listed in Table 1.

\subsection{RESPONSE VARIABLES}

Population viability was estimated by two measures, the proportion of replicate populations that persisted for 80 y (roughly 20 generations), and the spatially structured population's (SSP) growth rate, $\lambda$. Because females destined to spawn in different upstream reaches are counted at Lower Granite Dam, persistence is defined for the linked-population as a whole. We estimated persistence as the fraction of 200 replicate simulated populations that persisted for twenty generations (80 y). We estimated the intrinsic rate of increase, $r$ by fitting the equation to the simulated time-series of female spawner counts at Lower Granite Dam, $N(t)=N(t 0) e^{r(t-t 0)}$, for $r$ and defined $\lambda=e^{r}$, with the first five years removed to reduce the effects of initial conditions.

\subsection{JUVENILE LIFE HISTORY}

In the Snake River, a proportion, $P_{y}$, of juveniles remain in the river during their first year and migrate to sea during their second spring when they are yearlings (reservoir-type, $k=1$ ). The remainder emigrate as sub-yearlings (ocean-type, $k=0$ ) (Connor et al. 2002). Connor et al. found that a higher proportion of juveniles emigrated as yearlings in cooler tributaries such as the Clearwater River than emigrated as yearlings from the warmer mainstem Snake River. Overall, Connor et al. (2005) estimated that 46.5\% of females returning to spawn and captured at Lower Granite Dam between 1998 and 2003 had emigrated as yearlings.

The initial proportion of fish of each life history was determined as follows. First, we estimated proportions for each of four spawning areas for historical years between 1991 and 2005. We used Connor et al.'s field estimates when they were available and imputed missing values using temperature data and growth thresholds identified by Perkins and Jager (2011). To simulate proportions in each future year, we selected an historical year at uniform random and adopted its yearling proportion, whether imputed or measured. Thereafter, the model tracked how many female spawners belong to each strategy and allocated their female eggs proportionally, where the count was drawn from a beta-binomial distribution using $P_{y}$ as the mean. Overdispersion was estimated from the four spawning areas $\left(P_{y c v}\right.$ in Table 2). 
Table 1. Parameters in the Snake River fall Chinook metapopulation model. Acronyms include Hells Canyon (HC) population and dam, Lower Granite (LG),

\begin{tabular}{|c|c|c|}
\hline Parameter & Value & Description \\
\hline Num_iter & 200 & Number of iterations (populations) for each scenario \\
\hline Nvary & 0 & Number of parameters to vary, generating scenarios \\
\hline Begin_yr & 1990 & Start year \\
\hline End_yr & 2070 & End year \\
\hline NO & 20,000 & Initial numbers of females in population \\
\hline Nsub & 4 & Number of subpopulations (spawning areas) \\
\hline Oc_last & 0.75 & $\begin{array}{l}\text { Proportion of year (fall-fall) spent in ocean before up-migration to } \\
\text { spawn }\end{array}$ \\
\hline Oc-0 & 0.1 & $\begin{array}{l}\text { Proportion of year spent in ocean after out-migration for sub- } \\
\text { yearling outmigrants }\end{array}$ \\
\hline Oc-1 & 0.7 & $\begin{array}{l}\text { Proportion of year spent in ocean after out-migration for yearling } \\
\text { outmigrants }\end{array}$ \\
\hline SR_model & 0 & $\begin{array}{l}\text { 0=Beverton-Holt, 1=Hierarchical Bayesian Ricker, 2=Shepherd, } \\
3=\text { Hill-Ricker model }\end{array}$ \\
\hline$\propto$ & 0.0045 & $\begin{array}{l}\text { Maximum per-capita recruitment in the absence of density- } \\
\text { dependent effects (millions); Based on SR fitting to (Milks et al. } \\
\text { 2009) }\end{array}$ \\
\hline Fec_avg & 3,688 & $\begin{array}{l}\text { Average per-capita fecundity, used in hatchery simulation (Milks et } \\
\text { al. 2009) }\end{array}$ \\
\hline$K_{\text {pop }}$ & 5,000 & Habitat capacity (number of female spawners) fitted to LG returns \\
\hline$L_{\max }$ & 86.331 & $\begin{array}{l}\text { Maximum size - for age } 6(\mathrm{~cm}) \text { in fitted logistic growth curve, } \\
\text { Equation } 5\end{array}$ \\
\hline$X S$ & 0.5557 & Standard deviation of age in logistic growth curve, Equation 5 \\
\hline$x 0$ & 1.5302 & Age at inflection point in logistic growth curve, Equation 5 \\
\hline Stochastic & 1 & Simulate stochastic survival and proportions \\
\hline ScV & 0.25 & $\begin{array}{l}\text { Default coefficient of variation on beta-binomial survival for those } \\
\text { lacking estimates (Struck_LG, Sriver_LG, Shatch0, Shatch1 in Table } \\
\text { 2); MCMC analysis result, } 0.2373 \text {. }\end{array}$ \\
\hline $\mathrm{NoPy}$ & 0 & Flag to "turn off” yearling juvenile life history \\
\hline Bool_trapmark & 1 & $\begin{array}{l}\text { Trap1_mark and Trap2_mark (see definitions below and in Table 5) } \\
\text { are } 0 / 1 \text { values if this is one. }\end{array}$ \\
\hline Struck_up & 0.91 & $\begin{array}{l}\text { Survival of translocation is assumed to be similar to pre-spawning } \\
\text { mortality, Spre }\end{array}$ \\
\hline Sfact & Varied & $\begin{array}{l}\text { Ratio of egg-smolt survival in the new habitat above Brownlee Dam } \\
\text { vs. the downstream HCC habitat, multiplies } S_{E G G}\end{array}$ \\
\hline Kfact & Varied & $\begin{array}{l}\text { Ratio of carrying capacity in new habitat above Brownlee Dam vs. } \\
\text { the downstream HCC habitat, multiplies } K_{\text {pop }}\end{array}$ \\
\hline Tdown & 0.80 & $\begin{array}{l}\text { Proportion of juveniles trapped upstream of Brownlee Reservoir } \\
\text { while moving downstream. (Chandler and Chapman 2001) }\end{array}$ \\
\hline Trans_mark & Table 5 & $\begin{array}{l}\text { Vector indicating whether or not excess fish with this mark are } \\
\text { translocated, values are } 0 / 1\end{array}$ \\
\hline Yr_newpop1 & 2020 & Initial year of introducing new population \\
\hline Yr_newpop2 & 2080 & Final year of supplementing new population \\
\hline
\end{tabular}




\begin{tabular}{|l|l|l|}
\hline Fhatch0 & 0.0 & $\begin{array}{l}\text { Fraction of spawners taken to hatchery, offspring released as sub- } \\
\text { yearlings (age 0) }\end{array}$ \\
\hline Fhatch1 & 0.0 & $\begin{array}{l}\text { Fraction of spawners taken to hatchery, offspring released as } \\
\text { yearlings (age 1) }\end{array}$ \\
\hline Ktrap_min & $\begin{array}{l}\text { MCMC } \\
\text { (Table 4) }\end{array}$ & $\begin{array}{l}\text { Fraction of current trapping rate at start of historical stocking (linear } \\
\text { increase) }\end{array}$ \\
\hline $\begin{array}{l}\text { Up1_quota, } \\
\text { Up2_quota }\end{array}$ & $1,600,1,600$ & $\begin{array}{l}\text { Quota for broodstock removed at each of two traps. Females } \\
\text { removed at Lyons Ferry, (Milks et al. 2009) }\end{array}$ \\
\hline Qjuv1_below & 450,000 & Quota on yearling releases below HCC, (Milks et al. 2009) \\
\hline Qjuv1_above & 0 & Quota on yearling releases above HCC \\
\hline $\begin{array}{l}\text { Trap1_year, } \\
\text { Trap2_year }\end{array}$ & 1985,2005 & First year of trap operation for traps below LG and HC Dams. \\
\hline Trap1_mark \& & Table 5 & $\begin{array}{l}\text { Vector indicating adults with this mark used as broodstock, see } \\
\text { Bool_TrapMark, or proportion taken from fish with this mark; 0/1 }\end{array}$ \\
\hline Grid_start & Varied & Vector of initial values of gridded parameter search \\
\hline Grid_end & Varied & Vector of final values of gridded parameter search \\
\hline Grid_step & Varied & Vector of step sizes (positive) or multiplier (negative) \\
\hline MCdata & Varied & Name of csv file with MCMC parameter chain \\
\hline Parm_name & Varied & Vector of parameter names, of size Nvary \\
\hline Parm_min & Varied & Vector of minimum values of prior distribution \\
\hline Parm_max & Varied & Vector of maximum values of prior distribution \\
\hline Prior_dist & Varied & Vector of prior distributions (beta, Gaussian, Poisson) \\
\hline $\begin{array}{l}\text { Prior_mu, } \\
\text { Prior_sd }\end{array}$ & Varied & Vector of mean, sd of prior distributions \\
\hline SA_init & Varied & $\begin{array}{l}\text { Vector of starting parameter values in search (alternative to drawing } \\
\text { from priors) }\end{array}$ \\
\hline SAR_target0 & 0.004 & $\begin{array}{l}\text { Target value for subyearling smolt-to-adult survival, from historical } \\
\text { data }\end{array}$ \\
\hline SAR_target1 & 0.006 & $\begin{array}{l}\text { Target value for yearling smolt-to-adult survival, from historical } \\
\text { data }\end{array}$ \\
\hline
\end{tabular}


Table 2. Summary of stochastic models for demographic rates in the LPVA.

\begin{tabular}{|c|c|c|c|c|c|c|}
\hline Rate or percentage & Parameter & Mean & $\begin{array}{l}\mathrm{CV}=\mathrm{SE} / \\
\text { mean }\end{array}$ & Varies by & Distribution & Reference \\
\hline $\begin{array}{l}\text { Upmigration survival } \\
\text { to LGR }\end{array}$ & $S_{U P 1}, S_{U P 1 \_C V}$ & 0.646 & 0.015 & & $\begin{array}{l}\text { Beta- } \\
\text { binomial }\end{array}$ & $\begin{array}{l}\text { Upmigration survival from ocean to above } \\
\text { LG Dam from adult pit tags, 2002-2007 } \\
\text { average wild and hatchery , SE from digitized } \\
\text { graph 1986-2006 and appendix in (NOAA } \\
\text { Fisheries 2008); Includes in-river harvest. }\end{array}$ \\
\hline $\begin{array}{l}\text { Upmigration survival } \\
\text { LGR to Snake }\end{array}$ & $S_{U P 2}, S_{U P 2 \_C V}$ & 0.710 & $\begin{array}{l}\text { Same as } \\
\text { above }\end{array}$ & & $\begin{array}{l}\text { Beta- } \\
\text { binomial }\end{array}$ & $\begin{array}{l}\text { Adult survival of upmigration from LG to } \\
\text { spawning grounds in the Snake River } \\
\text { (Chapman et al. 1994); Includes in-river } \\
\text { harvest. }\end{array}$ \\
\hline Percent female & $\begin{array}{l}\text { Pfemale, } \\
\text { Pfemale_cv }\end{array}$ & 0.4314 & 0.0113 & & $\begin{array}{l}\text { Beta- } \\
\text { binomial }\end{array}$ & $\begin{array}{l}\text { Proportion of adult spawners that are female } \\
\text { (eggs assumed to be 50:50); Lyons Ferry } \\
\text { Hatchery data 1990-2002, adult broodstock }\end{array}$ \\
\hline Egg sex ratio & $\begin{array}{l}\text { Egg_ratio, } \\
\text { Pfemale_cv }\end{array}$ & 0.5 & 0.0113 & & $\begin{array}{l}\text { Beta- } \\
\text { binomial }\end{array}$ & $\begin{array}{l}\text { Lyons Ferry Hatchery data 1990-2002, } \\
\text { offspring }\end{array}$ \\
\hline Spawner-recruit error & $0, S R \_C V$ & 0.0 & 0.0003 & & $\begin{array}{l}\text { Normal for } \\
\log (\mathrm{R} / \mathrm{S})\end{array}$ & Analysis of return data, millions of recruits \\
\hline $\begin{array}{l}\text { Early survival from } \\
\text { egg to spring when } \\
\text { sub-yearlings } \\
\text { become smolt and } \\
\text { yearlings remain } \\
\text { residualized }\end{array}$ & $\begin{array}{l}S_{E G G} \\
E n v \_c V\end{array}$ & 0.125 & 0.0 & Population & $\begin{array}{l}\text { Beta- } \\
\text { binomial }\end{array}$ & $\begin{array}{l}\text { MCMC (Table 4); Estimates: } 0.105 \text { in } \\
\text { (Groves and Chandler 2003) \& } 0.292 \text { in } \\
\text { (McMichael et al. 2005) }\end{array}$ \\
\hline Percent yearling type & $P_{y}(\mathrm{t}), P_{y c v}(\mathrm{t})$ & & $\begin{array}{l}\text { Annual SE } \\
\text { calculated } \\
\text { based on } \\
\text { mean, }\end{array}$ & Population & $\begin{array}{l}\text { Beta- } \\
\text { binomial }\end{array}$ & $\begin{array}{l}\text { Mean Py drawn annually based on historical } \\
\text { proportions (Perkins and Jager 2011); Each } \\
\text { year's CV calculated based on deviations } \\
\text { from mean. }\end{array}$ \\
\hline $\begin{array}{l}\text { Percent of yearlings } \\
\text { above LG over } \\
\text { winter }\end{array}$ & PyLGRes & 0.50 & 0.0 & & Poisson & $\begin{array}{l}\text { Proportion of yearling type that overwinter } \\
\text { above Lower Granite Dam, influences } \\
\text { yearling SAR. Calibrated to smolt-to-adult } \\
\text { return ratio for yearling-outmigrant-type }\end{array}$ \\
\hline $\begin{array}{l}\text { Survival sub-yearling } \\
\text { smolts from Snake }\end{array}$ & $S_{L G, 0,} S_{L G, 0 \_c v}$ & 0.6297 & 0.0236 & & $\begin{array}{l}\text { Beta- } \\
\text { binomial }\end{array}$ & $\begin{array}{l}\text { Pittsburg Landing trap to LG Dam tailrace } \\
\text { (Connor et al. 2004) }\end{array}$ \\
\hline
\end{tabular}




\begin{tabular}{|c|c|c|c|c|c|c|}
\hline River to LG tailrace & & & & & & \\
\hline $\begin{array}{l}\text { Survival yearling } \\
\text { smolts from Snake } \\
\text { River to LG tailrace }\end{array}$ & $S_{L G, 1,} S_{L G, 1 \_c v}$ & 0.9344 & 0.0083 & & $\begin{array}{l}\text { Beta- } \\
\text { binomial }\end{array}$ & $\begin{array}{l}\text { Pittsburg Landing trap to LG Dam tailrace } \\
\text { (Connor et al. 2004) }\end{array}$ \\
\hline $\begin{array}{l}\text { Survival sub-yearling } \\
\text { smolts from LG } \\
\text { tailrace to below } \\
\text { Bonneville Dam }\end{array}$ & $S_{B O N, 0,} S_{B O N, 0 \_c v}$ & 0.3685 & 0.1205 & & $\begin{array}{l}\text { Beta- } \\
\text { binomial }\end{array}$ & $\begin{array}{l}\text { See section 1.5.1; DART analysis, Connor } \\
\text { pc. 2006; SE from (Muir et al. 2006) for } \\
\text { spring Chinook; }\end{array}$ \\
\hline $\begin{array}{l}\text { Survival yearling } \\
\text { smolts from LG } \\
\text { tailrace to below } \\
\text { Bonneville Dam }\end{array}$ & $S_{B O N, 1}, S_{B O N, 1 \_c v}$ & 0.538 & 0.112 & & $\begin{array}{l}\text { Beta- } \\
\text { binomial }\end{array}$ & (Williams et al. 2005, Faulkner et al. 2007) \\
\hline $\begin{array}{l}\text { Estuary survival, } \\
\text { sub-yearling }\end{array}$ & $S_{E S T, 0,} S_{E S T, 0 \_c v}$ & 0.588 & 0.0 & & $\begin{array}{l}\text { Beta- } \\
\text { binomial }\end{array}$ & $\begin{array}{l}\text { Bonneville Dam tailrace through estuary } \\
\text { (McMichael et al. 2007) }\end{array}$ \\
\hline $\begin{array}{l}\text { Estuary survival, } \\
\text { yearling }\end{array}$ & $S_{E S T, 1,} S_{E S T, 1 \_c v}$ & 0.653 & 0.0 & & $\begin{array}{l}\text { Beta- } \\
\text { binomial }\end{array}$ & $\begin{array}{l}\text { Bonneville Dam tailrace through estuary } \\
\text { (McMichael et al. 2007) }\end{array}$ \\
\hline Ocean survival & $\begin{array}{l}S_{O C, \min }, S_{O C, \max } \\
\text { Soc_cV }\end{array}$ & $\begin{array}{l}0.0100 \\
0.8415\end{array}$ & 0.0256 & & $\begin{array}{l}\text { Beta- } \\
\text { binomial }\end{array}$ & $\begin{array}{l}\text { Equation 5; Lower bound varied (MCMC); } \\
\text { Upper estimates: 0.8, (Ricker 1976); 0.885 in } \\
\text { nineties (Myers et al. 1998); Max 1986-2006 } \\
\text { was 0.797 (NOAA Fisheries 2008) }\end{array}$ \\
\hline $\begin{array}{l}\text { Ratio of yearling } \\
\text { age- } 0 \text { survival in } \\
\text { reservoirs to sub- } \\
\text { yearlings survival } \\
\text { during the same time } \\
\end{array}$ & $S_{R E S \_O C}$ & $\begin{array}{l}\text { Table } 4 \\
\text { (MCMC) }\end{array}$ & 0.0 & & Poisson & $\begin{array}{l}\text { Survival while migrating to the ocean and } \\
\text { spending time in the ocean, respectively. } \\
\text { Estimates of reservoir survival are } 0.13-0.22 \\
\text { over summer; } 0.65 \text { over winter. (Muir et al. } \\
\text { 1999, Connor et al. 2003) }\end{array}$ \\
\hline $\begin{array}{l}\text { Proportion trapped, } \\
\text { up }\end{array}$ & $\begin{array}{l}\text { Trap1_up, } \\
\text { Trap2_up }\end{array}$ & $\begin{array}{l}0.2, \\
\text { Varied }\end{array}$ & $0.0,0.0$ & Trap & Poisson & 20\% of hr, 24h/d, (Milks et al. 2009) \\
\hline $\begin{array}{l}\text { Survival to release } \\
\text { for hatchery } \\
\text { juveniles released as } \\
\text { sub-yearlings, } \\
\text { yearlings }\end{array}$ & $\begin{array}{l}\text { Shatch_0, } \\
\text { Shatch_1 }\end{array}$ & $\begin{array}{l}0.893 \\
0.816\end{array}$ & ScV & & $\begin{array}{l}\text { Beta- } \\
\text { binomial }\end{array}$ & $\begin{array}{l}\text { Lyons Ferry Hatchery averages 1990-2003 } \\
\text { (Milks et al. 2009) }\end{array}$ \\
\hline $\begin{array}{l}\text { Survival of juveniles } \\
\text { migrating in-river } \\
\text { from above } \\
\text { Brownlee Dam to }\end{array}$ & Sriver_LG & 0.3 & $S \_C V$ & & $\begin{array}{l}\text { Beta- } \\
\text { binomial }\end{array}$ & (Chandler and Chapman 2001) \\
\hline
\end{tabular}




\begin{tabular}{|l|l|l|l|l|l|l|}
\hline below LGR & & & & & & \\
\hline $\begin{array}{l}\text { Survival of juveniles } \\
\text { trucked downstream } \\
\text { to below LG Dam }\end{array}$ & Struck_LG & 0.8 & S_CV & & $\begin{array}{l}\text { Beta- } \\
\text { binomial }\end{array}$ & (Chandler and Chapman 2001) \\
\hline $\begin{array}{l}\text { Proportion stocked in } \\
\text { new population }\end{array}$ & Pnew & $0.0,0.0$ & $0.0,0.0$ & & Poisson & $\begin{array}{l}\text { No current plans to stock upstream } \\
\text { population }\end{array}$ \\
\hline Proportion marked & $\begin{array}{l}\text { Pmarked, } \\
\text { Pmarked_cv }\end{array}$ & 0.76 & 0.06 & $\begin{array}{l}\text { Same for } \\
\text { age-0 and 1 }\end{array}$ & $\begin{array}{l}\text { Beta- } \\
\text { binomial }\end{array}$ & W. Connor personal communication \\
\hline $\begin{array}{l}\text { Broodstock pre- } \\
\text { spawn survival }\end{array}$ & Spre & 0.91 & 0.0 & & $\begin{array}{l}\text { Lyons Ferry Hatchery } \\
\text { binomial }\end{array}$ \\
\hline
\end{tabular}




\subsection{POPULATION DYNAMICS}

The number of female fall Chinook salmon, $n_{k, \mathrm{x}}$ in age class $\mathrm{x}$ belonging to life history type $k$ includes females from age $x$ to $x+1$ in year $t$ (Equation 1). The LPVA model increments salmon ages from the time of spawning in fall and measures survival from one fall to the next (post-census). Survival from age $\mathrm{x}$ to $\mathrm{x}+1$ is denoted $s_{x}$, and a second subscript is added to indicate life history type, where $s=$ sub-yearling $(k=0)$ and $y=$ yearling life history $(k=1)$ (Equation 1$)$.

$$
\begin{aligned}
& n_{k, 1}(t+1)=n_{k, 0}(t) \times\left\{\begin{array}{l}
\left(1-p_{y}\right) s_{0 s}, k=0 \\
p_{y} s_{0 y}, k=1
\end{array}\right. \\
& n_{k, 2}(t+1)=n_{k, 1}(t) \times\left\{\begin{array}{l}
\left(1-p_{y}\right) s_{1 s}, k=0 \\
p_{y} s_{1 y}, k=1
\end{array}\right.
\end{aligned}
$$

For adults ages 2 and older, we assume that the two life-history types ( $k=0$ and 1$)$ experience the same survival rates (Equation 2). Survival for these ages includes post-spawning mortality. Of those adults that were spawned 3-years previously, proportion $b_{3}$ migrate to spawn in the following fall, and fraction $S_{u p}=S_{u p 1} \times S_{u p 2}$, survive upstream migration. The Ns surviving females age 2 to 5 are counted as they swim upstream past Lower Granite Dam.

$$
\begin{gathered}
n_{k, x+1}(t+1)=s_{x} n_{x}(t), \text { age } x=2 \text { to } 5 \\
n_{k, x}(0)=\left\{\begin{array}{r}
\left(1-P_{y}\right) P_{x} N(0), \quad k=0 \\
\left(P_{y}\right) P_{x} N(0), \quad k=1
\end{array}\right. \\
N s_{k}(t)=S_{u p} \sum_{x=3}^{6} b_{i} n_{k, x}(t)
\end{gathered}
$$

Spawning females collectively produce offspring ( $n_{k, 0}$ in Equation 4$)$, apportioned among the two life history types, $k$. Density dependence in recruitment is simulated using a stock-recruitment relationship that applies to offspring from both hatchery and wild spawners. Two approaches can be used to represent density dependence. One relies on fitted data to returns and assumes that recruits are age- 1 fish in fall. The second approach, used here, begins with an assumed fecundity, $\alpha$ (maximum recruitment) and then applies density dependence as one source of mortality among others that occur during the first year of life. Either a Ricker model (centered to reduce correlation between parameters) or a Beverton-Holt model is permitted. Initial comparisons of alternative models for density dependence showed little ability to discriminate among models when fit to back-calculated data. We chose the Beverton-Holt relationship instead of the Ricker form for three reasons: First, it avoids the possibility of "crossing-over" when varying the upstream carrying capacity (lower recruits with a higher capacity) because the recruits from two capacities are additive. Second, there has been little evidence of over-compensation through the period of high spawner returns 2009 to 2012. Third, predictions from the Beverton-Holt model (Equation 4) are more conservative. The carrying capacity, $K_{\text {pop}}$, was estimated from previous efforts to fit Equation 4 to back-calculated $S(t)$ (Table 1 ). The capacity of the upstream, new spawning habitat is obtained by multiplying $K_{\text {pop }}$ by parameter, Kfact. Note that the number of recruits in Equation 4 accounts for all density dependence during the first year of life. 


$$
\begin{aligned}
& \text { Let } S(t)=\sum_{k=0}^{1}\left[N s_{k, \text { wild }}(t)+N s_{k, \text { hatchery }}(t)\right] \quad \text { (total female spawners) } \\
& n_{k, 0}(t+1)=\frac{\alpha S(t)}{\left(1+\frac{S(t)}{\hat{K}_{p o p}}\right)} \quad \text { (Spawner - recruit relationship) }
\end{aligned}
$$

Let $N(\mathrm{t})$ denote the total abundance of the Snake River population at time t, with initial value, $N(0)$. We adopted the stable age distribution as our initial age distribution, Pinit_age (Table 3) and assigned an initial juvenile life history based on vector $P y$, drawn from a list of historical annual values.

Table 3. Input parameters by age include the initial allocation of individuals by age, and the cumulative proportion of female spawners returning to the mainstem Snake River. Stable age distribution was used to estimate Pinit_age. The likelihood of spawning at age $x+1$, given survival to age $\mathrm{x}$ is obtained from Cmature (mean) and Cmat_CV (CV). Values are based on adult returns to Lyon's Hatchery between 1990 and 2006 (excluding 1995-7, 2001) (Milks et al. 2009).

\begin{tabular}{|l|l|l|l|l|l|l|}
\hline Parameter & Age 1 & Age 2 & Age 3 & Age 4 & Age 5 & Age 6 \\
\hline Pinit_age & 0.7453 & 0.2034 & 0.0416 & 0.0076 & 0.0018 & 0.0030 \\
\hline Cmature & & 0.05 & 0.2932 & 0.7474 & 0.9913 & 1.000 \\
\hline Cmat_CV & & 1.808 & 0.7615 & 0.2219 & 0.0126 & 0.0009 \\
\hline
\end{tabular}

\subsection{VARIATION IN DEMOGRAPHIC RATES}

Demographic stochasticity can be important for forecasts of future viability. For example, Zabel and Levin (2002) highlighted the sensitivity of PVA results to age structure. Many stochastic features of our PVA model involve drawing counts from a beta-binomial distribution to account for heterogeneity in probabilities among individuals, leading to over-dispersion (i.e., variance $>$ mean), see Teerapabolarn and Boondirek (2010). Mean rates were drawn from a beta distribution on the interval between zero and one. These rates were then used to draw a count of individuals (those that belong to a given gender or age category or that survive a threat) from a binomial distribution. We obtained estimates of means and $\mathrm{CV}=$ standard error (SE)/mean from the literature or from data when possible, as described below. When no estimate of the CV was available, we used a Poisson distribution (i.e., no over-dispersion). Assumptions about stochastic elements are summarized in Table 2.

Demographic stochasticity due to fluctuation in sex-ratio was represented by assuming that no recruitment occurs in years when, by chance, males are absent. Each year a random number of male spawners was drawn from a binomial distribution with proportion male, $P_{m} \sim \operatorname{beta}(\alpha, \beta)$. In our data, the proportion of female returns over eleven years showed low variation $(\mathrm{SE}=0.005, \mathrm{CV}=0.011)$. We determined the number of female eggs following reproduction using a Poisson distribution with mean 0.5 (Jensen and Hyde 1971), and similar variability to that observed later in life.

Stochasticity in survival was represented by drawing $n_{k, i}(t+1)$ from a negative binomial distribution with a quadratic mean-variance relationship (LeCam 1960, Linden and Mantyniemi 2011) with mean $\lambda=\#$ female spawners $x(1-$ Pfemale $)$ and coefficient of variation, Pfemale_cv. Our efforts to relate environmental stochasticity to ocean conditions revealed a weak relationship with ocean climate, in contrast to previous analyses for spring Chinook salmon (Zabel et al. 2006). Consequently we did not include ocean influences, but the model can represent climate influence on incubation survival if such an effect is detected. 


\subsection{JUVENILE SURVIVAL}

We assume that first-year survival differs for sub-yearling emigrants and juveniles that exit as yearlings (Equation 1). We distinguish five time periods through which juveniles must survive: (1) the period from egg to emergence as fry and development into smolts (rearing), (2) downstream migration survival from above Lower Granite Dam (LG) in the Snake River to below LG, (3) survival from the LG Dam tailrace to the Bonneville Dam tailrace, (4) survival through the unimpounded Lower Columbia River and estuary before reaching the ocean, and (5) ocean survival during the remainder of the year.

For both juvenile life histories, first-year survival includes the rearing period from egg to smolt. Survival of the rearing period ranges from 6 to 15\% below Hells Canyon Dam, with 46.5\% survival to emergence (Groves and Chandler 2003) and the remaining mortality after emergence and before emigration of subyearlings in late-spring.

\subsubsection{SUB-YEARLING LIFE HISTORY}

Jolly-Seber-Cormack survival estimates for juveniles migrating downstream rely on release and recapture data from PIT-tagged juveniles released upstream and tracked using detectors at each of eight downstream dams. Unfortunately, detection probabilities are not high enough to permit estimates of survival all the way from the Snake River to below Bonneville Dam. This problem is circumvented by multiplying average survival from the Snake River to LG and from juveniles released below LG to below McNary Dam, and from below McNary Dam to below Bonneville Dam. According to Williams et al. (2008), sub-yearling survival through the eight-dam hydrosystem lies between 0.05 and 0.25 . A morerecent estimate by Rechisky et al. (2009) found 40\% survival for larger (>140 mm) smolts released at Kooskia National Fish Hatchery above Dworshak Dam in the Clearwater River.

Snake-LG—Survival of marked juveniles to LG has been shown to increase with size (Connor et al. 2004) and decrease with temperature (Connor et al. 2003). Survival has been shown to be lower for later outmigrants (0.20 in September) than for earlier emigrants (0.45-076 in May-June) (Smith et al. 2003). We take our estimate of SE from Muir et al. (2006), who estimated migration survival of spring Chinook smolts in six years $(1997-2002)$ as $0.4702(\mathrm{SE}=0.0444)$. For fall Chinook, we calculated a weighted average of $S_{L G R, 0}=0.6297$ based on a 1997-1998 study of hatchery juveniles PIT-tagged and released from Pittsburg Landing and detected passing LG Dam (Connor et al. 2004). Connor (personal communication) estimated survival of surrogate juvenile fall Chinook in 2006 as 0.4146.

LG-Bonneville-Two recent Jolly-Seber-Cormack estimates of survival from LG Dam to below Bonneville Dam, averaged $S_{B O N, 0}=0.3685$. We estimated survival from LG Dam to below Bonneville based on detection data from a transportation study in 2004 as 0.3224 . Marked yearling individuals that remain in reservoirs until winter and are detected the following year were removed from the estimates, but concerns about violating the assumption of constant likelihood of detection remain.

Estuary_Estimates of estuary survival of sub-yearling fall Chinook, $S_{E S T, 0}$ from the Bonneville Dam tailrace to the mouth of the Columbia River, a distance of $226 \mathrm{~km}$ traveled in 4-5 days, ranged from 0.15 to 1.0 [average $0.588 \pm 0.083$; (McMichael et al. 2007)]. A later study of survival in the Columbia River below Bonneville indicated that survival was quite variable (Clemens et al. 2009). Sub-yearlings arrive in the estuary during spring and summer, after which we apply ocean survival, $S_{O C, 0}$ from summer to fall.

Total first-year survival is simulated as the product of survival through four periods: egg-to-smolt, outmigration from the Snake River to LG, LG to Bonneville, estuary-to-ocean by August, followed by a

final quarter year in the ocean $\left(S_{O C, O}\right)^{\text {OC-0 }}$. During their second year of life, we assume that sub-yearling emigrants are exposed to a full year of ocean mortality, $S_{O C, 1}$. 
We did not consider different routes of downstream transportation of juveniles to the estuary. Downstream transportation of juveniles is a controversial management tool that could have an important effect on overall survival during the second year of life. However, evidence that transportation has a significant effect, delayed or otherwise, seems to be evaporating under continued scrutiny. Juvenile survival estimates were similar for spring Chinook migrating through the six of the dams in the hydrosystem (mean $=0.486$, range 0.279 to 0.578 ) and for transported juveniles (mean $=0.553$, range 0.336 to 0.683 , including delayed mortality) (Williams et al. 2005). Delayed mortality was not significantly greater than one in any year between 1994 and 2004 (Schaller and Petrosky 2007) and was not consistent with results of a survival study tracking large fall Chinook smolts released in the Clearwater River and monitored by an offshore ocean array (Rechisky et al. 2009).

\subsubsection{YEARLING LIFE HISTORY}

Yearling-type fish remain in the river through the fall of their first year and exit during late winter. They then traverse the estuary, and spend the remainder of their second year in the ocean. For the remainder of the first year, between spring emigration of sub-yearlings and fall birth date, we represent reservoir survival as a multiplier of ocean survival contemporaneously experienced by sub-yearlings, $S_{R E S}=S_{R E S \_O C}$ $S_{O C, 0}$. We calibrated $S_{R E S_{-} O C}$, along with the proportion remaining above Lower Granite Dam, $P$, against the yearling smolt-to-adult return ratio. Our best estimate of survival during the second year (from fall) is the product of (1) survival of fall Chinook salmon during downstream migration from above LG Dam in the Snake River to below LG Dam, $S_{L G R, 1}$, (2) survival while migrating downstream from the LG tailrace to the Bonneville Dam tailrace, $S_{B O N, 1,}$ (3) estuary survival, $S_{E S T, 1}$, and (4) ocean survival during the remaining quarter-year to the following fall, $\left(S_{O C, 1}\right)^{O C-1}$.

Faulkner et al. (2007) estimated survival of yearlings through the eight-dam hydrosystem from the Snake River trap (located at rkm 224.6 near the Clearwater R. confluence) to the Bonneville Dam tailrace for each year from 1999 and 2006 (average 0.4804). This is within the range of other published survival estimates (0.3102 to 0.5232), obtained by combining releases at rkm 341 on the Snake River detected at Lower Granite Dam with releases from the LG tailrace detected in the Bonneville Dam tailrace (see below).

Snake-LG.-Average survival of hatchery fall Chinook released as yearlings from Pittsburg Landing (rkm 341) in 1997 and 1998 was 0.9079 (standard error, SE = 0.015; (Connor et al. 2004)). Estimated survival between 2001 and 2006 of wild yearlings from the Snake River trap at the head of LG (rkm 224.6) to the LG Dam tailrace averaged 0.9438 ( $\mathrm{SE}=$ 0.034; (Williams et al. 2005, Faulkner et al. 2007). We use the weighted average of these two estimates, $S_{L G R, 1}=0.9344$ for this period. The reported survival of wild yearlings from the Salmon River trap to the LG tailrace was lower, 0.862 (Williams et al. 2005).

LG-Bonneville.-Survival of out-migrating yearling fall Chinook is not known at the time of this study. We therefore assume that survival is the same as survival of yearling spring Chinook, which has increased over time, possibly in response to improvements at the dams and in flow regimes (Williams et al. 2005). An early estimate of out-migration survival during the period 1977-1979 was 0.095 (Marmorek et al. 1998, cited by Kareiva et al. (2000). Recent survival estimates, derived from PIT-tag data for wild and hatchery yearling spring Chinook salmon migrating downstream from above Lower Granite Reservoir to below Bonneville Dam, are higher. Smith et al. (2010) reported an average hydro-system survival of 0.332 between 1993 and 2004. Williams et al. (2005) reported a somewhat higher estimate, 0.464 (SE = 0.052), for the period from 1997-2003. Ferguson (2007) estimated 2007 yearling survival through all 8 reservoirs and dams as 0.56 . We estimated $S_{B O N, 1}=0.5142\left(=0.4804 \div S_{L G R, 1}\right)$ to be consistent with Faulkner et al.’s (2007) estimate, which includes the whole river starting from the Snake River down.

Estuary — Survival of yearlings from below Bonneville Dam to the mouth of the Columbia River estuary, 
a distance of $226 \mathrm{~km}$ travelled, on average, over 4.1 days, ranged from 0.57 to 0.66 [avg. 0.615;

(Ferguson 2007)]. This estimate is considerably higher than an earlier one using an inverse method $\left(S_{E S T, 1},=0.017\right)$ (Kareiva et al. 2000)(Wilson 2003). McMichael et al. (2007) reported twelve estimates of estuary survival for yearlings during 2005 and 2006, averaging $S_{E S T, 1}=0.653 \pm 0.046$ (range 0.564 to 0.873).

\subsection{ADULT SURVIVAL}

Adult fall Chinook migrate farther north along the North Pacific coast with age, where they are exposed to fisheries from the coast of Oregon and Washington up to West Vancouver Island, Central British Columbia, and Alaska (Norris et al. 2000). Snake River fall Chinook Columbia River apparently do not move as far north as stocks that spawn farther downstream (Norris et al. 2000). Most individuals marked at Lyons Ferry Hatchery (30\% of age-3 adults, $27 \%$ of age- 4 adults, and $24 \%$ of age- 5 adults) migrated to the area west of Vancouver Island and the Queen Charlotte Islands, but sizable fractions of adults age 4 (24\%) and 5 (41\%) continued on to the coast of Alaska (Norris et al. 2000).

Ocean survival has varied over time: The ocean exploitation rate, $S_{O C}$, for fall Chinook decreased from 34.9\% between 1982 and 1989 [PSC 1994 in Myers et al. (1998)], to 11.5\% in 1995 and 23\% in 1996 (Myers et al. 1998). In our model, we assume that females of age $x$ in the ocean survive at rate $S_{O C, x}$ (Tables 1, 3). We simulate size-dependent predation by piscivores and other marine predators, $S_{o c, x}$ (Equation 5; Figure 1), where a logistic equation for average fork length was fitted to length data for subyearlings and yearlings passing Bonneville Dam for ages 1 and 2 (Connor personal communication via 2008 presentation) and to average sizes of female spawners for ages 3 to 6 (Milks et al. 2009). In Equation 5, $S_{o c, \max }$ is the maximum survival and $L_{\max }$ the average size of age-6 female spawners (Table 2).

$$
\begin{aligned}
& S_{o c, x}=S_{o c, \min }+\left(S_{o c, \max }-S_{o c, \min }\right)\left(\frac{\left(L_{x}-L_{0}\right)}{L_{\max }-L_{0}}\right), \\
& \text { where } L_{x}=\frac{L_{\max }}{1+\exp \left[\frac{-(x-x 0)}{x s}\right]} \text {. }
\end{aligned}
$$

We estimated maximum ocean survival from exploitation rates, $Z$, for wild Snake River fall Chinook salmon for 1986-2006 (NOAA Fisheries 2008) as $S_{o c, \max }=\exp (-Z)$. Because the lower bound, $S_{o c, \min }$, is the only component of survival with no measured estimate, we estimated the posterior distribution of parameters using the MCMC procedure described in section 3. 


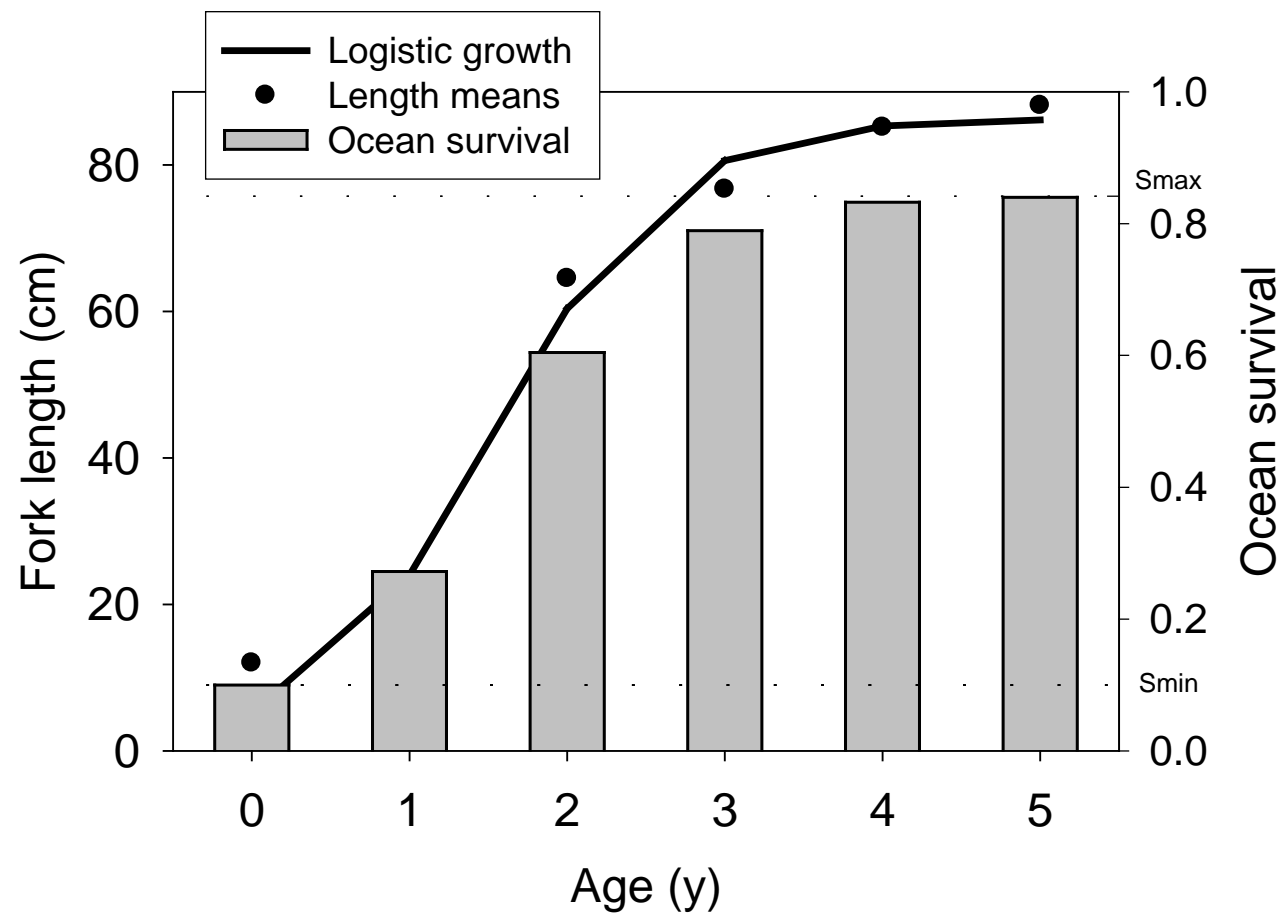

Figure 1. Size-dependent model of ocean survival between limits $S_{o c, \min }$ and $S_{o c, \max }$.

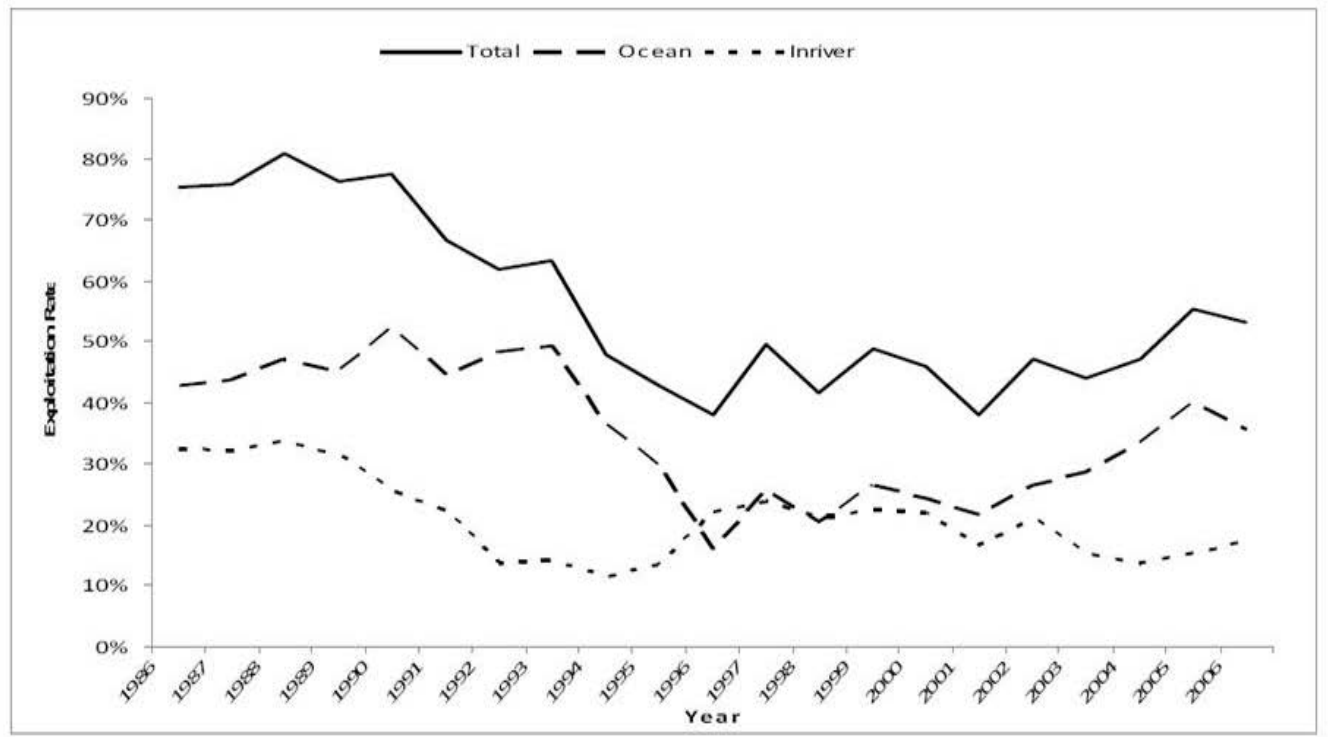

Figure 2. Ocean and in-river exploitation rates (percent of upmigrating spawners counted at Bonneville Dam) for Snake River fall Chinook. Source: (NOAA Fisheries 2008). 
LPVA assumes that all females that attempt a spawning migration die within the same year. However, to back-calculate the number of females at each reproductive age in winter from counts the following fall, we require an estimate of survival from winter to fall of the year of spawning. We assume that females of age $i$ intending to spawn during the next year spend $O c_{-}$last $=3 / 4$ of the year (December to August) in the ocean, with survival $S_{O C, i}$. Not all females that attempt migration are counted at Lower Granite Dam because a sizable fraction dies during migration up river, represented by $S_{U P 1}$. During the 1990's, upmigration survival to LG estimated based on pit-tagged adults observed above LG was 0.55 (Peters et al. 2001). This estimate did not separate males from females, but jacks were excluded. We used a more recent estimate, the unadjusted Bonneville-to-LG conversion rate, $S_{U P 1}=0.645$, which was reported in a Biological Opinion by NOAA Fisheries (2008). Approximately half of mortality during upmigration is caused by harvest within the Lower Columbia River; Survival of in-river harvest alone averaged 0.79 between 1987 and 2006 (NOAA Fisheries 2008) (Figure 2). The exploitation rate within the Lower Columbia River decreased since the mid-1980's [Table 1, Pacific Salmon Commission 1994 in (Myers et al. 1998)], but has more-recently increased (Figure 2).

Tribal harvest in the Snake River between Lower Granite pool and their spawning destinations is believed to be low. We estimated survival through this final, pre-spawning period as $S_{U P 2}=0.71$ based on

comparing counts of upmigrating adults with redd counts. Chandler and Chapman (2001) used a fallback estimate of 35\% to adjust escapement data for 1993 and 2000. Fish-per-redd estimates ranged from 2.0 to 3.6, suggesting an average mortality between passing LG Dam and spawning in the Snake River of 0.29 for adults passing LG. Upon reaching the spawning ground, most, but not all, females survive to spawn, $S_{\text {pre }}$ (Table 1).

\subsection{REPRODUCTION}

Spawner-recruitment (SR) relationships are typically used to model reproduction. In the simulations reported here, we used a mechanistic approach to simulating recruitment to age 1. Female offspring that survive to age 1 were estimated from females surviving to reach the spawning grounds based on fecundity, density dependence, and estimates of juvenile survival. Most females spawn between the ages of three and five. We allocated ocean females among ages at return using $P_{\text {init_age }}(x)$, the proportion surviving to age $x$ that spawn before reaching age $x+1$ (Table 3). This number of females was reduced by removing females used for translocation or broodstock at the two traps, and estimating the female spawners surviving upstream migration to LG, $S_{U P 1}$ and from LG to the Snake River below Hells Canyon, $S_{U P 2}$.

Egg production in the new population was calculated by applying mortality to females that were translocated upstream (presumably with males). The model provides for different egg-to-smolt survival in the new population. We simulated density dependence with a habitat capacity of 5,000 females below Hell's Canyon Dam based on peak returns to LG observed during 2009-2012. Maximum fecundity was based on hatchery estimates. We then applied mechanistic sources of first-year mortality described earlier. Finally, we estimated and reported the model-simulated spawner recruitment parameters for comparison against empirically-derived values, which are currently being constructed.

The model provides for an alternative empirical approach that estimates a spawner-recruitment relationship for age- 1 females empirically by back-calculating from census counts of female adults returning to LG Dam. When this approach is used, mechanistic sources of mortality during the first year are not applied. 


\section{BAYESIAN MULTI-PARAMETER MODELING \& SENSITIVITY ANALYSIS}

We implemented a Bayesian approach to estimate the posterior distributions of poorly-known parameters, $\bar{\theta}$, given historical data $(\boldsymbol{D}=$ spawner returns to Lower Granite Dam, 1961-2011), as shown in Equation 6. The LPVA compares with data from two sources, historical spawner abundances and average smoltto-adult return ratios (SAR) at LG for the two juvenile life histories. Between 1990 and 2001, averages based on studies of coded-wire tag juveniles detected upon returning to spawn indicate that roughly $0.4 \%$ of juveniles released as sub-yearlings and $0.615 \%$ of juveniles released from Lyons Ferry hatchery as yearlings returned to Lower Granite Dam as adults. Likelihoods are estimated separately for the two types of data, as described below, and combined by multiplying.

The posterior distribution is the stationary distribution of the chain (Marjoram et al. 2003), as shown in Equation 6.

$$
P(\bar{\theta} \mid \vec{D})=\frac{\pi(\bar{\theta}) P(D \mid \bar{\theta})}{P(D)}
$$

Following Piou et al. (2009), we began by assigning prior distributions, $\pi_{j}$ (Table 4). Two survival parameters $\left(S_{E G G}\right.$ and $\left.S_{O C, \min }\right)$ and $K_{\text {trap_min }}$ were assigned beta-distributed priors; The ratio $S_{R E S \_O C}$ was assigned a Gaussian prior distribution (Table 4).

Table 4. Parameters of prior distributions and hyper-parameters used in estimating the posterior distribution of four poorly known LPVA parameter consistent with available historical data for spawner returns.

\begin{tabular}{|l|l|l|l|l|l|}
\hline Parameter & Distribution & Mean & SD & Minimum & Maximum \\
\hline$K_{\text {trap } \min }$ & Beta & 0.10 & 0.01 & 0.00 & 0.8 \\
\hline$S_{E G G}$ & Beta & 0.15 & 0.01 & 0.0 & 0.7 \\
\hline$S_{O C, \min }$ & Beta & 0.05 & 0.005 & 0.0 & 0.5 \\
\hline$S_{R E S \_O C}$ & Gaussian & 2.0 & 0.1 & 0.0 & 3.0 \\
\hline
\end{tabular}

We simulated a Monte Carlo Markov chain of length 100,000. For each iteration, a new parameter vector, $\bar{\theta}$ ', was independently drawn from a joint, independent prior distribution, $\pi$. For each multivariate draw, we estimated the negative log-likelihood, $P O M=-2 \Sigma_{\mathrm{t}} \log \left(L\left(D_{\mathrm{t}} \mid \bar{\theta}\right)\right)$ using a kerneldensity estimation approach that can be used for black-box models (Marjoram et al. 2003, Piou et al. 2009). We used a Metropolis-Hastings algorithm to simulate a Markov chain to estimate the posterior distribution. Each parameter's jump distribution was $\mathbb{N}(\mathbf{0}, \mathbf{V})$, where $v_{i i}=\sigma ; v_{i j}=0$. The jump distribution can be optionally adapted by varying $\sigma$ (Roberts and Casella 2010) (Shaby and Wells 2011), as part of the Langevin adaptive procedure, where

$$
\sigma_{t}=\sqrt{\sigma_{t-1}^{2} e^{\left(\frac{1}{t}\left[r_{t}-r_{o p t}\right]\right)}}
$$

$r_{t}$ is the acceptance rate at step $\mathrm{t}$ and $r_{\text {opt }}=0.234$ is the optimal acceptance rate. Proposed vectors $\bar{\theta}$, falling outside the specified parameter domain were rejected, as recommended (Gelman et al. 2004, Roberts and Casella 2010). Parameter sets within the specified domain and leading to higher likelihoods $L(\bar{\theta}$ ' $\mid \boldsymbol{D})$ were accepted and those within the domain with lower likelihoods were accepted with 
probability, $r=\frac{P\left(\theta^{\prime} \mid D\right)}{P(\theta \mid D)}=\frac{\pi\left(\theta^{\prime}\right) L\left(D \mid \theta^{\prime}\right)}{\pi(\theta) L(D \mid \theta)}$.

We characterized the posterior distribution of four parameters (Figure 3). The historical data was able to resolve these four parameters fairly well, as evidenced by the well-defined peaks (Figure 3).

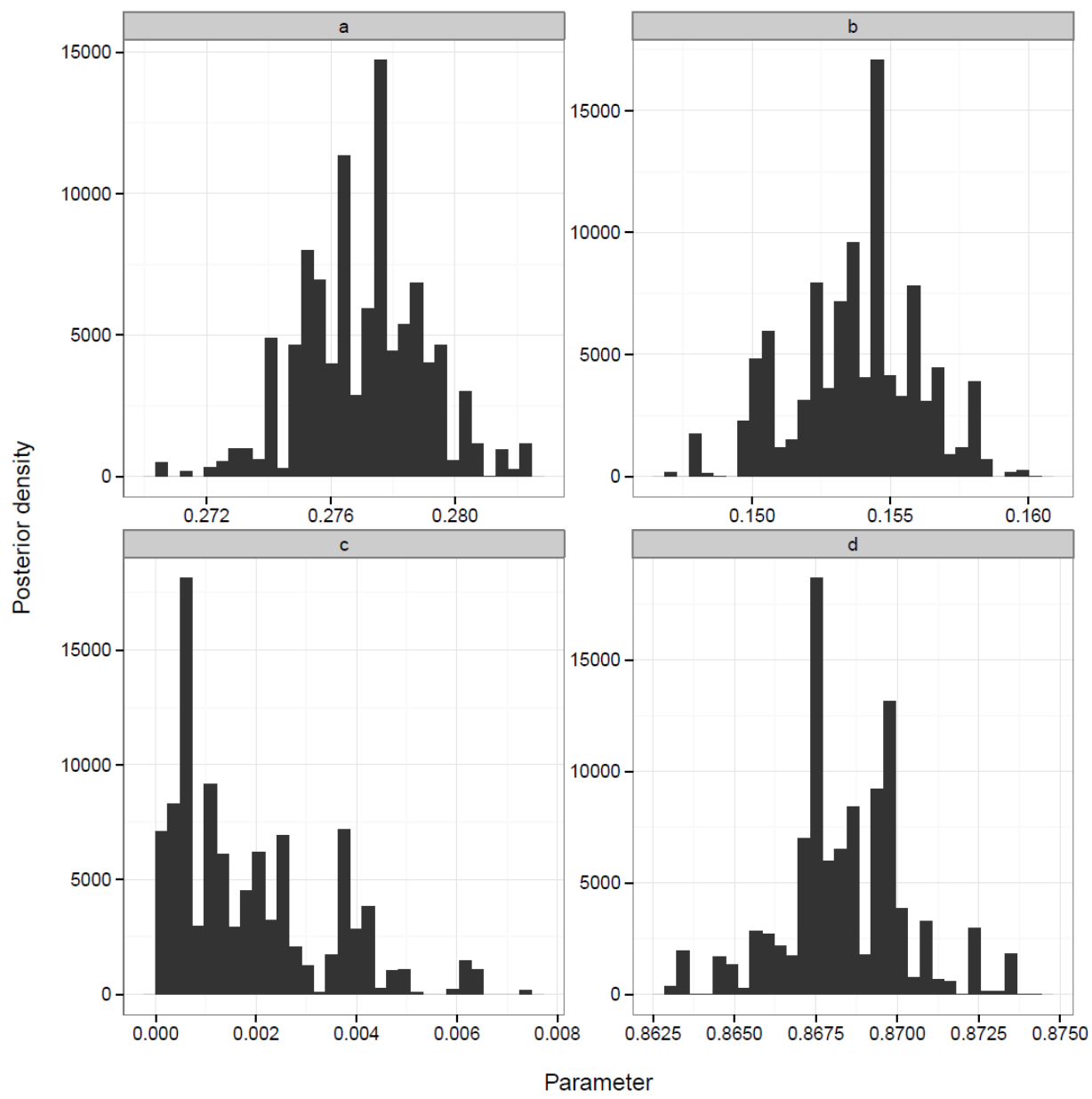

Figure 3. MCMC-estimated posterior distributions of four poorly-known parameters, a) $K_{\text {trap_min, }}$ b) $S_{E G G,}$ c) $S_{O C, \min }$, and d) $S_{R E S \_O C}$.

We conducted ensemble modeling of future persistence under different reconnection scenarios. This was accomplished by simulating from the posterior chain of parameters. We sampled this distribution by retaining the final 10,000 vectors. The following options are provided for running the LPVA with more than one parameter set, selected through parameter switch MC_method:

1) Generate a grid of values for an arbitrary number of parameters, specifying minimum, maximum, and step size, where a negative step size is used to indicate a multiplicative change.

2) Use Gibbs sampling to estimate the joint posterior distribution of parameters (rejection sampling).

3) Use the Metropolis-Hastings algorithm described earlier, updating all parameters as a single block, with either adaptive or non-adaptive sampling.

4) Conduct simulated annealing to find the maximum likelihood parameter set. 
5) Read-in a previously generated list of parameters.

6) Read-in a previously generated list of parameters and combine with all possible combinations of a grid. This method is used to project alternative reconnection scenarios for a chain of equallylikely parameter alternatives.

After following this procedure, we used regression tree analysis to explore the importance of management variables, including up and downstream trapping rates, spawning the ratio of habitat capacity above Brownlee to that below Hells Canyon, and survival of early life stages in Brownlee Reservoir relative to that below Hells Canyon.

To assess sensitivity, a sensitivity program was developed in R. This program calculates partial correlations between model-simulated results (historical population trends) for each parameter vector and the individual parameter values.

\section{SIMULATING REINTRODUCTION OPTIONS}

The purpose of the LPVA model was to assess the benefits to the overall fall Chinook salmon ESU of introducing a new upstream population. LPVA represents supplementation options and to evaluate their effectiveness in supporting the Hells Canyon fall Chinook salmon ESU. LPVA tracks cohorts defined by four attributes: 1) population, 2) age in y, 3) juvenile list history type, and 4) mark type. One option for introducing a "new" population of fall Chinook salmon above the Hells Canyon Complex (HCC) is to use hatchery supplementation of the Brownlee reach. The approach is general, allowing two hatcheries, one drawing from adult returns below Lower Granite Dam (LG) and one drawing from adult returns below Hell's Canyon Dam (HC). Processes simulated for each hatchery include i) trapping of adults for broodstock, ii) survival of broodstock, iii) egg production and survival, iv) division into release groups by destination (below HC and above Brownlee) and by age at release (age-0 and age-1), v) division into cohorts with different marks, and vi) simulation of downstream migration through two routes, as depicted by Figure 4 . 


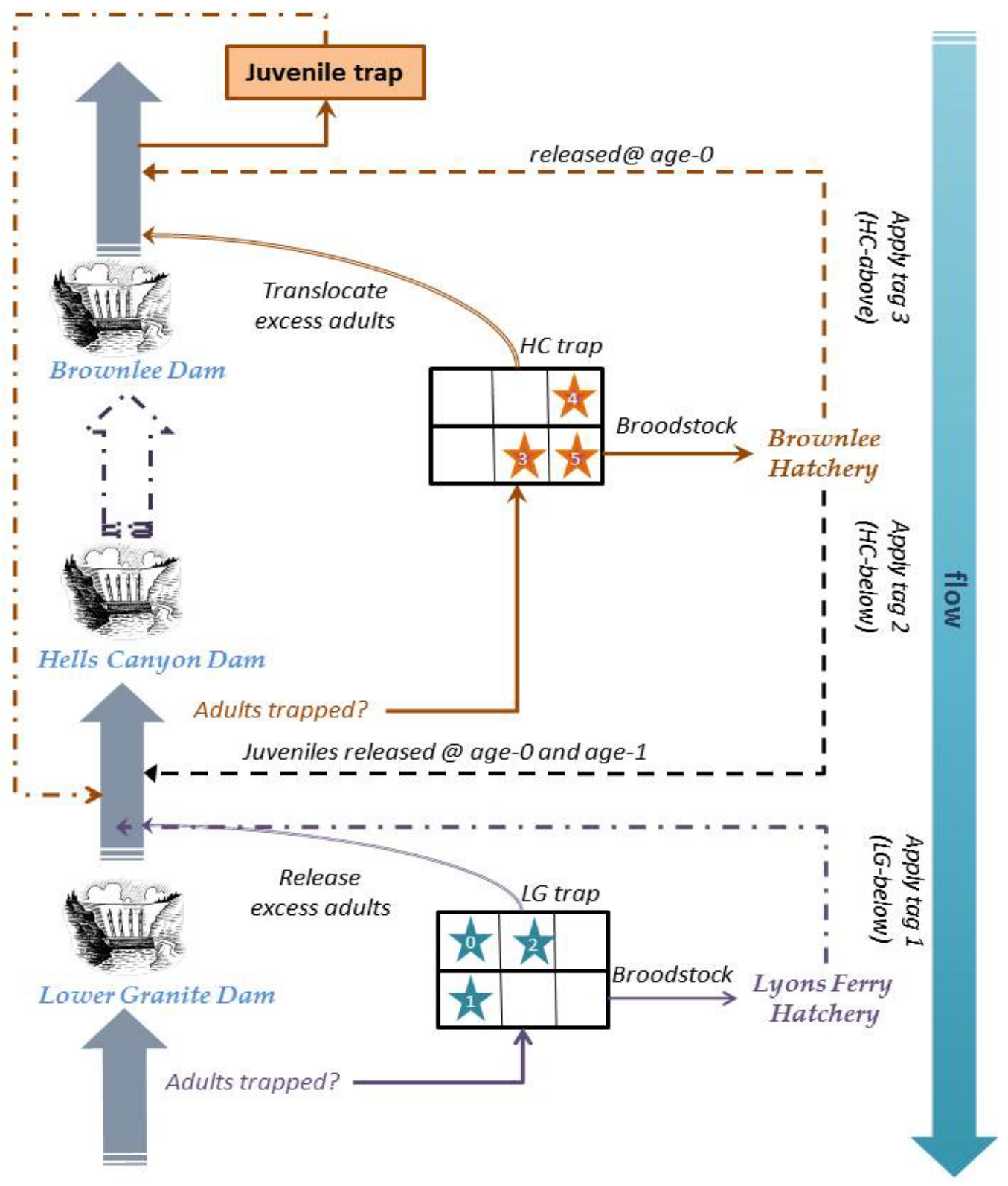

Figure 4. Diagram of the simulated reintroduction decision process. 
At each node, demographic stochasticity is simulated via binomial decisions (i.e., for individuals within an age class-). Individual variation in probabilities is simulated using a beta-binomial distribution as described by Link and Hahn (1996), which makes use of coefficients of variation, such as Scv. These parameters are described in Table 2.

Adult trapping._-Adult trapping begins at a specified year for each trap, Trap1_year and Trap2_year (Table 1). During years of operation, the hatchery module removes broodstock by capturing upmigrating females that return to LG with rate, Trap1_up. This rate was estimated from operational data from traps at LG. This rate was estimated from operational data from traps at Lyons Ferry Hatchery. The rate of upstream trapping, $\lambda$, is assumed to increase over time, $t$, mirroring historical trends in juvenile releases of hatchery fish.

$$
\lambda(t)=T r a p \_r a t e \_u p \frac{\left(1-K t r a p \_ \text {min }\right)\left(t-\text { Trap } 1 \_y e a r\right)}{\left(\text { Trap_yr_historic } 2-T r a p 1 \_y e a r\right)}
$$

In future simulations, those reaching the upstream trap were removed at rate, Trap2_up.

Efforts to maintain a new, distinct population above the HCC depends on the ability to determine adult origin and prevent introgression. The main tool for doing this is selective removal of adults with different marks indicating origin at the two traps. Six possible marks distinguish salmon with different histories (Table 5).

Table 5. Marks distinguishing Snake River fall Chinook salmon caught and released at different locations.

\begin{tabular}{|c|c|c|c|c|c|c|c|}
\hline $\begin{array}{l}\text { Mark } \\
\text { id }\end{array}$ & $\begin{array}{l}\text { Previous } \\
\text { mark }\end{array}$ & Trap & Origin & $\begin{array}{l}\text { Site or event } \\
\text { of last } \\
\text { marking }\end{array}$ & Marks & $\begin{array}{l}\text { Translocate } \\
\text { excess fish? }\end{array}$ & $\begin{array}{l}\text { Disposition } \\
\text { upon return as } \\
\text { adult }\end{array}$ \\
\hline $\begin{array}{l}0 \\
\text { (none) }\end{array}$ & none & $\begin{array}{l}\text { Unknown } \\
\text { origin }\end{array}$ & Unknown & Unknown & none & no & $\begin{array}{l}\text { Downstream } \\
\text { trap }\end{array}$ \\
\hline 1 & none & $\begin{array}{l}\text { LG dam } \\
\text { trap }\end{array}$ & $\begin{array}{l}\text { Below } \\
\text { HCC }\end{array}$ & $\begin{array}{l}\text { LF hatchery } \\
\text { (ponded fry) }\end{array}$ & adipose fin clip & no & $\begin{array}{l}\text { Downstream } \\
\text { trap; } \\
\text { Upstream trap } \\
\text { only during } \\
\text { transition. }\end{array}$ \\
\hline 2 & none & $\begin{array}{l}\text { HC dam } \\
\text { trap }\end{array}$ & \begin{tabular}{|l} 
Below \\
HCC \\
\end{tabular} & $\begin{array}{l}\text { BR hatchery } \\
\text { (ponded fry) }\end{array}$ & mandible clip & yes & $\begin{array}{l}\text { Upstream trap } \\
\text { only }\end{array}$ \\
\hline 3 & none & \begin{tabular}{|l|} 
HC dam \\
trap
\end{tabular} & $\begin{array}{l}\text { Above } \\
\text { HCC }\end{array}$ & $\begin{array}{l}\text { BR hatchery } \\
\text { (ponded fry) }\end{array}$ & $\begin{array}{l}\text { mandible }+ \\
\text { adipose clip }\end{array}$ & yes & $\begin{array}{l}\text { Upstream trap } \\
\text { only }\end{array}$ \\
\hline 4 & none & $\begin{array}{l}\text { Brownlee } \\
\text { (natural) } \\
\text { juvenile } \\
\text { trap }\end{array}$ & $\begin{array}{l}\text { Below } \\
\text { HCC }\end{array}$ & $\begin{array}{l}\text { Translocation } \\
\text { release site; } \\
\text { Brownlee } \\
\text { trap }\end{array}$ & $\begin{array}{l}\text { mandible + left } \\
\text { ventral } \\
\text { (translocated } \\
\text { parents) }\end{array}$ & yes & $\begin{array}{l}\text { Upstream trap } \\
\text { only }\end{array}$ \\
\hline 5 & 3 & $\begin{array}{l}\text { Brownlee } \\
\text { (hatchery) } \\
\text { juvenile } \\
\text { trap }\end{array}$ & \begin{tabular}{|l} 
Below \\
HCC
\end{tabular} & $\begin{array}{l}\text { BR hatchery; } \\
\text { Brownlee } \\
\text { trap }\end{array}$ & $\begin{array}{l}\text { mandible + } \\
\text { adipose + left } \\
\text { ventral }\end{array}$ & yes & $\begin{array}{l}\text { Upstream trap } \\
\text { only }\end{array}$ \\
\hline
\end{tabular}


Although trap rates are indiscriminate, our trap quotas discriminate among returning females with different origins. The idea is that the trap catches all returning females with a given rate, but only those selected are removed either for use as broodstock or to be transported upstream. When parameter Bool_trapmark =1, Trap1_mark and Trap2_mark are zero-one vectors indicating whether or not females of a certain origin, indicated by marks in Table 5, should be removed. We also defined a transition period between the year of establishment for a new spawning population, $Y r \_n e w p o p 1$ and operation of the upstream trap below HC Dam. Negative values of Trap2_mark indicate that operations can be seeded using adults with these marks, but only during the transition period.

In our analyses, we assumed that the lower LG trap removed unmarked adults and those indicating origin below HCC, i.e., Mark id's 0, 1, and 2 (Table 5). We assumed that the upper trap (HC) removed females with marks 3, 4, and 5, (origin above the HCC). During the transition period, we permitted females with mark 1 (LF hatchery origin) to be removed at the upstream, HC trap.

Alternatively, Trap_mark vectors can be proportions summing to one, and thereby apportion the specified Up1_quota or Up2_quota among returning females with different marks. At the upper, HC trap, we translocated females captured beyond this quota above the HCC (Figure 4) if this was indicated by vector Trans_mark. We assumed that adults trapped at the lower LG trap would not be used to supplement the new, upstream spawning population.

Egg production.-Each year, the number of broodstock surviving pre-spawn mortality was drawn from a beta-binomial distribution with mean, Spre. On average, 50\% of eggs are assumed to be female, drawn using a binomial distribution. The number of green eggs surviving to release at ages zero and one are drawn from beta-binomial distributions with mean Shatch1 and Shatch2, respectively. Parameter values were estimated from data in reports from Lyons Ferry Hatchery (Milks et al. 2009).

At this point, surviving eggs are divided between juveniles to be released at age 1 and at age- 0 . We specify a quota of age- 1 releases and this quota is met before releasing age-0 eggs below, Qjuv1_below, or above, Qjuv1_above the HCC. Age-0 releases are added to the age-1 cohort, whereas eggs slated for release at age- 1 are stored until the following year and subsequently added to the age- 2 cohort. All surviving hatchery-reared juveniles are ultimately released.

The user specifies start and end years for implementation of a new population. Prior to the start year, hatchery offspring are added to the population below HCC. After the start year, hatchery offspring are divided between the habitat above and below HCC using a proportion Pnew specified for each trap. Different levels of age- 0 survival can be simulated. However, we expect that the poor water quality above HCC would actually lead to much lower survival.

Density dependence.-An important aspect of simulating hatchery supplementation is to represent the effects of adding juveniles on habitat capacity. To address this, the model now separates the non-densitydependent portion of reproduction and the density-dependent portion. After simulating maximum egg production, both wild and hatchery-produced, these are combined by population prior to estimating the reduction due to density-dependent effects. Because we already have eggs at this point, the model backestimates females and applies a Beverton-Holt relationship. Differences in habitat capacity for the two populations ( $\mathrm{Kr}$ = ratio of capacity above to below HCC) come into play here. The natural (translocated) and hatchery component are separated proportionally after recruitment to age- 1 has been estimated based on total density for each population.

Marking.-Evaluating population models against data is greatly facilitated when the model simulates the observation process, including sources of uncertainty. This is because nearly all observations rely on tracking of marked individuals. We assumed that a proportion of adults and juveniles is marked whenever captured in a trap, regardless of ultimate disposition. The number of hatchery juveniles that are marked was drawn with parameters mean proportion, Pmark, and CV, Pmark_cv.

Downstream migration. - Juveniles above HCC travel downstream to LG via two routes. First, trapping 
is simulated by specifying a downstream trapping rate, Tdown. This is done separately for cohorts with different marks. For age-0 releases, a Poisson count is drawn from both natural offspring of translocated females (if any) and age-0 hatchery releases. Migration survival from above HCC to LG is simulated for juvenile cohorts trapped and transported (average $=$ Struck_LG) and those migrating in-river (Sriver_LG) using beta-binomial distributions (Table 1, 2).

\section{CONCLUSIONS}

This report documents the methods to be used in evaluating the persistence of the Snake River fall Chinook salmon ESU under different management scenarios, including hatchery operations and trap-andtransport to spawning habitat above Brownlee Reservoir. The results of the simulations of these scenarios are reported elsewhere. 


\section{REFERENCES}

Chandler, J. A. and D. W. Chapman. 2001. Feasibility of Reintroduction of Anadromous Fish Above or Within the Hells Canyon Complex. Technical Report Appendix E.3.1-2, Idaho Power Company, Boise, Idaho.

Chapman, D., A. Giorgi, T. Hillman, D. Deppert, M. Erho, S. Hays, C. Peven, B. Suzumoto, and R. Klinge. 1994. Status of summer/fall chinook salmon in the mid-Columbia region. Report for Chelan, Douglas, and Grant County PUD's, Don Chapman Consultants, 3653 Rickenbacker, Ste. 200, Boise, ID 83705.

Clemens, B. J., S. P. Clements, M. D. Karnowski, D. B. Jepsen, A. I. Gitelman, and C. B. Schreck. 2009. Effects of Transportation and Other Factors on Survival Estimates of Juvenile Salmonids in the Unimpounded Lower Columbia River. Transactions of the American Fisheries Society 138:169188.

Connor, W. P., H. L. Burge, R. Waitt, and T. C. Bjornn. 2002. Juvenile life history of wild fall chinook salmon in the snake and clearwater rivers. North American Journal of Fisheries Management 22:703-712.

Connor, W. P., H. L. Burge, J. R. Yearsley, and T. C. Bjornn. 2003. Influence of flow and temperature on survival of wild subyearling fall chinook salmon in the Snake River. North American Journal of Fisheries Management 23:362-375.

Connor, W. P., S. G. Smith, T. Andersen, S. M. Bradbury, D. C. Burum, E. E. Hockersmith, M. L. Schuck, G. W. Mendel, and R. M. Bugert. 2004. Postrelease performance of hatchery yearling and subyearling fall Chinook salmon released into the Snake river. North American Journal of Fisheries Management 24:545-560.

Connor, W. P., J. G. Sneva, K. F. Tiffan, R. K. Steinhorst, and D. Ross. 2005. Two alternative juvenile life history types for fall Chinook salmon in the Snake River basin. Transactions of the American Fisheries Society 134:291-304.

Faulkner, J. R., S. G. Smith, W. D. Muir, D. M. Marsh, and J. G. Williams. 2007. Survival estimates for the passage of spring-migrating juvenile salmonids through Snake and Columbia River Dams and Reservoirs, 2006. NOAA Fisheries.

Ferguson, J. W. 2007. Preliminary survival estimates among large west coast rivers.in N. Fisheries, editor. Memo to ruce Suzumoto.

Gelman, A., J. B. Carlin, H. S. Stern, and D. B. Rubin. 2004. Bayesian Data Analysis. 2nd edition. Chapman and Hall/CRC Press.

Groves, P. A. and J. A. Chandler. 2003. The quality and availability of fall Chinook salmon spawning and incubation habitat downstream of the Hells Canyon Complex. FERC No. 1791, Idaho Power Company, Boise, Idaho.

Jensen, P. T. and J. Hyde. 1971. Sex ratios and survival estimates among salmon populations. Cal-Neva Wildlife Transactions:20-27.

Kareiva, P., M. Marvier, and M. McClure. 2000. Recovery and management options for spring/summer chinook salmon in the Columbia River Basin. Science 290:977-979.

LeCam, L. 1960. An approximation theorem for the Poisson binomial distribution. Pacific Journal of Mathematics 10:1181-1197.

Linden, A. and S. Mantyniemi. 2011. Using the negative binomial distribution to model overdispersion in ecological count data. Ecology 92:1414-1421.

Link, W. A. and D. C. Hahn. 1996. Empirical Bayes Estimation of Proportions with Application to Cowbird Parasitism Rates. Ecology 77:2528-2537.

Marjoram, P., J. Molitor, V. Plagnol, and S. Tavare. 2003. Markov chain Monte Carlo without likelihoods. Proceedings of the National Academy of Sciences 100:15324-15328.

McMichael, G. A., C. L. Rakowski, B. B. James, and J. A. Lukas. 2005. Estimated fall Chinook salmon survival to emergence in dewatered Redds in a shallow side channel of the Columbia River. North American Journal of Fisheries Management 25:876-884. 
McMichael, G. A., J. A. Vucelick, B. J. Bellgraph, T. J. Carlson, R. L. McCoas, L. G. Gilbreath, S. G. Smith, B. P. Sandford, G. M. Matthews, and J. W. Ferguson. 2007. A study to estimate salmonid survival through the Columbia River estuary using acoustic tags, 2005 and 2006 Synthesis Report. PNNL-SA-54927, Pacific Northwest National Laboratory.

Milks, D., M. Varney, and M. Schuck. 2009. Lyons Ferry Hatchery Evaluation Fall Chinook Salmon Annual Report: 2006. Fish Program Report Number FPA 09-04, U.S. Fish and Wildlife Service.

Muir, W. D., D. M. Marsh, B. P. Sandford, S. G. Smith, and J. G. Williams. 2006. Post-hydropower system delayed mortality of transported Snake River stream-type Chinook salmon: Unraveling the mystery. Transactions of the American Fisheries Society 135:1523-1534.

Muir, W. D., S. G. Smith, E. E. Hockersmith, M. B. Eppard, W. P. Connor, T. Andersen, and B. D. Arnsberg. 1999. Fall Chinook salmon survival and supplementation studies in the Snake river and Lower Snake River reservoirs, 1997. Bonneville Power Administration, Portland, OR.

Myers, J. M., R. G. Kope, G. J. Bryant, D. Teel, L. J. Lierheimer, T. C. Wainwright, W. S. Grant, F. W. Waknitz, K. Neely, S. T. Lindley, and R. S. Waples. 1998. Status Review of Chinook Salmon from Washington, Idaho, Oregon, and California. NOAA Technical Memorandum NMFSNWFSC-35, U.S. Dept. Commerce.

NOAA Fisheries. 2008. Supplemental Comprehensive Analysis of the Federal Columbia River Power System and Mainstem Effects of the Upper Snake and other Tributary Actions. NOAA Fisheries.

Norris, J. G., S. Y. Hyun, and J. Anderson. 2000. Ocean distribution of Columbia River upriver bright Fall Chinook salmon stocks. North Pacific Anadromous Fisheries Commision Bulletin 2:221232.

Perkins, T. A. and H. I. Jager. 2011. Falling behind: Delayed growth explains life-history variation in Snake River fall Chinook salmon. Transactions of the American Fisheries Society 140:959-972.

Peters, C. N., D. R. Marmorek, and R. B. Deriso. 2001. Application of decision analysis to evaluate recovery actions for threatened Snake River fall chinook salmon (Oncorhynchus tshawytscha). Canadian Journal of Fisheries and Aquatic Sciences 58:2447-2458.

Piou, C., U. Berger, and V. Grimm. 2009. Proposing an information criterion for individual-based models developed in a pattern-oriented modeling framework. Ecological Modelling 220:1957-1967.

Rechisky, E. L., D. W. Welch, A. D. Porter, M. C. Jacobs, and A. Ladouceur. 2009. Experimental measurement of hydrosystem-induced delayed mortality in juvenile Snake River spring Chinook salmon (Oncorhynchus tshawytscha) using a large-scale acoustic array. Canadian Journal of Fisheries and Aquatic Sciences 66:1019-1024.

Ricker, W. E. 1976. Review of the rate of growth and mortality of Pacific salmon in salt water, and noncatch mortality caused by fishing. Journal of the Fisheries Research Board of Canada 33:14831524.

Roberts, C. and G. Casella. 2010. Introducting Monte Carlo Methods with R.in L. Springer Science+Business Media, editor.

Schaller, H. A. and C. E. Petrosky. 2007. Assessing hydrosystem influence on delayed mortality of Snake River stream-type Chinook salmon. North American Journal of Fisheries Management 27:810824.

Shaby, B. and M. Wells. 2011. Exploring an adaptive Metropolis algorithm. Department of Statistics, Duke University, Chapel Hill, NC.

Smith, D. L., J. M. Nestler, G. E. Johnson, and R. A. Goodwin. 2010. Species-Specific Spatial and Temporal Distribution Patterns of Emigrating Juvenile Salmonids in the Pacific Northwest. Reviews in Fisheries Science 18:40-64.

Smith, S. G., W. D. Muir, E. E. Hockersmith, R. W. Zabel, R. J. Graves, C. V. Ross, W. P. Connor, and B. D. Arnsberg. 2003. Influence of river conditions on survival and travel time of Snake River subyearling fall chinook salmon. North American Journal of Fisheries Management 23:939-961.

Teerapabolarn, K. and A. Boondirek. 2010. Negative binomial approximation with Stein's method and Stein’s identity. International Mathematical Forum 5:2541-2551.

Williams, J. G. 2008. Mitigating the effects of high-head dams on the Columbia River, USA: experience 
from the trenches. Hydrobiologia 609:241-251.

Williams, J. G., S.G. Smith, R.W. Zabel, W.D. Muir,, B. P. S. M.D. Scheuerell, D.M. Marsh, R.A., and S. A. McNatt. 2005. Effects of the federal Columbia River power system on salmonid populations. NMFS-NWFSC-63, U.S. Department of Commerce.

Wilson, P. H. 2003. Using population projection matrices to evaluate recovery strategies for Snake River spring and summer chinook salmon. Conservation Biology 17:782-794.

Zabel, R. W. and P. S. Levin. 2002. Simple assumptions on age composition lead to erroneous conclusions on the nature of density dependence in age-structured populations. Oecologia 133:349-355.

Zabel, R. W., M. D. Scheuerell, M. M. McClure, and J. G. Williams. 2006. The interplay between climate variability and density dependence in the population viability of Chinook salmon. Conservation Biology 20:190-200. 